IJMS 17 (1), 19-36 (2010)

\title{
PROTECTION OF INTELLECTUAL PROPERTY RIGHTS AN INDIAN PERSPECTIVE
}

\author{
BALAMURUGAN, R. \\ RADHAKRISHNAN, R. \\ Department of Electrical and Electronics Engineering \\ Anna University Coimbatore
}

\begin{abstract}
The objective of this paper is to provide an overview of the Indian Innovation System, IPR system and other related activities such as Judicial System, Enforcement System, and Academic Institutions etc. The paper is based on the existing data and relates those data and results to the India's Intellectual Property Rights System, Innovation, Research and Development. This paper focus on the recent reforms in IPR laws to achieve a legal framework for protecting IPR that is comparable to that of most developed nations. As a part Information Technology, three major IT organizations focus on innovation and research discussed in addition to an overview about major multinational companies' research initiatives in India.
\end{abstract}

Keywords: Intellectual Property Rights (IPR); World Trade Organization (WTO); Information Technology (IT); General Agreement on Tariffs and Trade (GATT); Agreement on Trade-Related Aspects of Intellectual Property Rights (TRIPS); International Searching Authority (ISA) and International Preliminary Examining Authority (IPEA).

\section{Intellectual Property Rights System in India: An Overview}

With increasing R\&D spending, over the past decade there has been a sharp increase in the level of IPR activities across the world. This reflects the growing importance of IPR in the knowledge - based economy, as the business community and research institutions are increasingly making use of IPRs to protect their inventions, and to make their investments in R\&D worthwhile. The World Trade Organization came into existence on 1st January, 1995, which is the successor of General Agreement on Tariffs and Trade (GATT). WTO's headquarter is located at Geneva, Switzerland and 
WTO deals with the rules of trade between nations at a near-global level and it is responsible for negotiating and implementing new trade agreements, and is in charge of policing member countries' adherence to all the WTO agreements. The organization is currently the host to new negotiations, under the Doha Development Agenda (DDA) launched in 2001. India is a founding member of WTO. WTO agreement contains an agreement on IPR, namely, the Agreement on Trade Related Aspects of Intellectual Property (TRIPS). This agreement made protection of IPR an enforceable obligation of the member countries and this agreement sets out minimum standards of IP protection for member states. India compiled with the obligations contained in the TRIPS Agreement and amended its IP laws. Whereas India's neighbour country China admitted into WTO in 2001 after a 15-year battle a monument change to the world trading system.

Intellectual Property Rights reflects the idea that its subject matter is the product of the mind or the intellect. The various IPRs are Patens, Trademarks, Copyrights, Geographical Indications, Industrial Designs, Layout-Design (Topographies) of Integrated Circuits, Plant Variety Protection. World Intellectual Property Organization (WIPO) administers treaties in the field of IPR, which a United Nations Organization's Agency, based in Geneva. In India, Department of Industrial Policy and Promotion (DIPP), Government of India is concerned with the legislations of Patents, Trademarks, Designs and Geographical Indications. All these are administered thorough the Office of the Controller General of Patents, Designs and Trademarks (OCGPDT), with headquarters at Mumbai. The following are the various Act related to IPRs in India.

a) The Patents Act, 1970(amended in 1999, 2002 and 2005) through the Patent Offices at Kolkotta (HQ), Mumbai, Chennai and Delhi.

b) The Designs Act, 2000 through the Patent Office at Kolkotta (HQ), Mumbai, Chennai and Delhi.

c) The Trademarks Act, 1999 through the Trade Marks Registry at Mumbai (HQ), Chennai, Delhi, Kolkotta and Ahemadabad.

d) The Geographical Indications of Goods (Registration and Protection) Act, 1999 through the Geographical Indications Registry at Chennai.

e) Copyright is protected through Copyright Act, 1957, as amended in 1999 - administered by the Department of Higher Education under Ministry of Human Resources Development.

f) Layout of transistors and other circuitry elements is protected through the Semi-conductor Integrated Circuits Layout-Designs Act, 2000. This is administered by the Department of Information Technology.

g) New varieties of plants are protected through the Protection of Plant Varieties and Farmers' Rights Act, 2001. This is administered by the Department of Agriculture and Cooperation. Department of IPP set up an Inter-ministerial Committee to coordinate. 


\section{IPR Enforcement Issues}

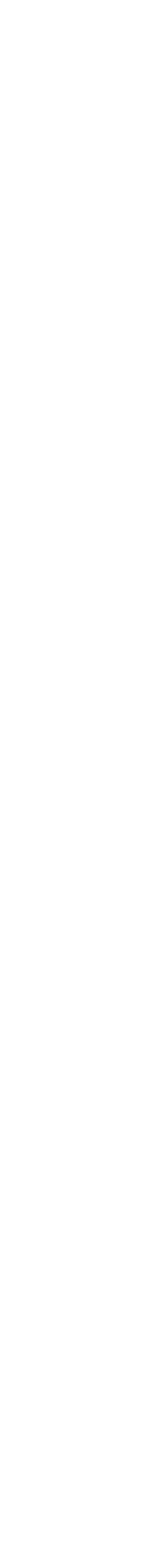

Along with the legislation, rules have been amended to install a userfriendly system for processing of IP applications. An Intellectual Property Appellate Board (IPAB) set up at Chennai to hear appeals against the decisions of Registrar of Trademarks, Geographical Indications and the Controller of Patents. Indian government in the last Five year plan went to upgrade, all Patent Offices located in Kolkotta, Delhi, Chennai and Mumbai. This process had completed during July, 2007. As a result of this the total number of patent applications filed had increased from 4824 (1999-2000) into 28, 882 (2006-2007). The total number of applications examined rose from 2824 (1999-2000) into 14, 119 (2006-2007). In Trademarks, the backlog of unexamined applications of approximately 0.5 million cases brought down to zero. Instantaneously renewal of trademarks certificates done in clear cases and within one week new applications is examined. This resulted in the increase of trademarks registration from 8, 010 (1999-2000) into 1,09,361 (2006-2007) (Source: www.ipindia.nic.in). During 2004-2005, 2005-2006 and 2006-2007, 0.338 million trademarks certificates were issued against only 0.165 million trademarks registered in 64 years (since 1940-2004). The following table shows how many utility patents were issued for a given year. Notice how the number has grown every decade.

Table 1

This Shows that Every Year There are more Opportunities for Inventions

\begin{tabular}{rrrr}
\hline Year & Patents & Year & Patents \\
\hline 1836 & 1 & 1936 & 2026516 \\
1846 & 4348 & 1946 & 2391856 \\
1856 & 14009 & 1956 & 2728913 \\
1866 & 51784 & 1966 & 3226729 \\
1876 & 171641 & 1976 & 3930271 \\
1896 & 552502 & 1986 & 4562596 \\
1906 & 808618 & 1996 & 5479658 \\
1916 & 1166419 & 2005 & 6836899 \\
1926 & 1568040 & & \\
\hline
\end{tabular}

Source. (Data from the U.S. Patent Office.).

India is a member of 2 major treaties, namely, Paris convention for the Protection of Industrial Property (relating to patents, trademarks, designs, etc.) of 1883 and the Berne Convention for the Protection of Literary and Artistic Works (relating to copyright) of 1886. India is also a member of Patent Cooperation Treaty (PCT) which facilitates to obtain patents in several nations by filing a single application. India also included as an International Searching Authority (ISA) and International Preliminary Examining Authority (IPEA) under the PCT. ISA and IPEAs provide search reports on novelty and examination reports on patentability of inventions.

IJMS 17 (1), 19-36 (2010) 
The details of list of treaties / conventions in which India is a signatory are WIPO Convention (05 January 1975), WTO-TRIPS (01 January 1995), Paris Convention (07 December 1998), Patent Cooperation Treaty (07 December 1998), Budapest Convention (17 December 2001), Berne Convention (01 April 1928) and UCC (07 January 1988).

\section{Table 2}

Top 10 Assignees for Indian Patent Publications, 1968-2004

1

\begin{tabular}{|rlrrr}
\hline \multicolumn{1}{|c}{ Rank } & \multicolumn{1}{c}{ Assignee/Applicant } & $\begin{array}{c}\text { Number of } \\
\text { Indian patents patents overall }\end{array}$ & $\begin{array}{c}\text { Number of } \\
\text { percentage of } \\
\text { totents }\end{array}$ \\
\hline 1 & Council Scient Ind Res & 3083 & 8510 & 36.22 \\
2 & Hindustan Lever Ltd & 946 & 3511 & 26.94 \\
3 & Hoechst & 766 & 170375 & 0.45 \\
4 & Siemens Ag & 685 & 498690 & 0.14 \\
5 & Westinghouse Electric Corp & 477 & 131175 & 0.36 \\
6 & Union Carbide Corp & 365 & 62677 & 0.58 \\
7 & Procter \& Gamble & 337 & 108401 & 0.31 \\
8 & Rieter Ag Maschf & 336 & 8649 & 3.88 \\
9 & Lucas Ind Plc & 326 & 31280 & 1.04 \\
10 & ICI Plc & 308 & 100722 & 0.31 \\
\hline
\end{tabular}

Source. INPADOC database on Dialog (http://scientific.thomson.com/news/newsletter/2007-11/8418387/).

Table 3

Top 10 Assignees for Indian Patent Publications, 2006

\begin{tabular}{|c|c|c|c|c|c|}
\hline \multirow{11}{*}{ D } & Rank & Assignee/Applicant & $\begin{array}{c}\text { Number of } \\
\text { Indian patents }\end{array}$ & $\begin{array}{c}\text { Number of } \\
\text { patents overall }\end{array}$ & $\begin{array}{l}\text { Percentage of } \\
\text { total patents }\end{array}$ \\
\hline & 1 & Microsoft Corp & 584 & 15223 & 3.84 \\
\hline & 2 & Council Scient Ind Res & 476 & 2152 & 22.12 \\
\hline & 3 & Johnson \& Johnson & 271 & 3691 & 7.34 \\
\hline & 4 & Qualcomm Inc & 249 & 3779 & 6.59 \\
\hline & 5 & Honda Motor Co Ltd & 237 & 45350 & 0.52 \\
\hline & 6 & Samsung Electronics & 216 & 126996 & 0.17 \\
\hline & 7 & Konink Philips Electric & 194 & 23008 & 0.84 \\
\hline & 8 & Thomson Licensing Sa & 157 & 3263 & 4.81 \\
\hline & 9 & Hindustan Lever Ltd & 146 & 2238 & 6.52 \\
\hline & 10 & Motorola Inc & 145 & 23193 & 0.63 \\
\hline
\end{tabular}

Source. DWPI database on Dialog.

22 IJMS 17 (1), 19-36 (2010) 


\section{Indian Innovation: Trends of Indian Economy}

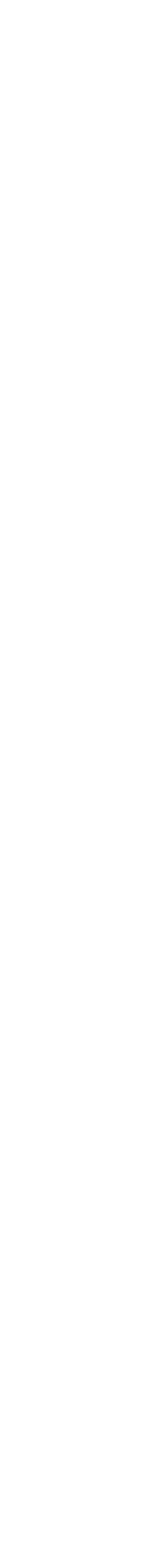

China and India both announced that innovation to be strategic national priorities. In January (2006), China unveiled its 15-year "Medium-to-LongTerm Plan for the Development of Science and Technology". This calls on China to become an "Innovation-Oriented Society" by the year 2020 and a global leader in Science and Technology by mid-century. This calls for steep increases in research and development (R\&D) expenditures over the next 15 years, from $1.23 \%$ of GDP in 2004 to $2.5 \%$ of a significantly larger GDP by 2020. India's FDI outflow estimated to exceed inflow in 2007-2008. The bulk of outward FDI flow drove mainly by India's booming manufacturing sector [Source: Study on FDI Outflow and amp; Role of Manufacturing sector, and amp; Acquisitions front 2007, by the Associated Chambers of Commerce and Industry (ASSOCHAM)]. As per the Economic Survey presented by the Indian Finance minister recently in the parliament, Indian economy moved decisively to a higher growth phase. The GDP exceeding $8 \%$ in every year since 2003-2004 and the projected economic growth in 2007-2008 was at $8.7 \%$.

\section{Innovation Index}

Innovation Index is a compilation of the Top 18 Innovators (revised to Top 20 Innovators) in North America. Most of these Innovators are prestigious companies including GE, 3M, HP, IBM, and Proctor \& Gamble who have created numerous innovations and shaped our lives over the past 50 plus years. Some leaders are better known by their innovative product brands Blackberry by Research In Motion, iPod and iMac by Apple, online shopping by Amazon.com, Windows and MS Office by Microsoft, Microprocessor powered by Intel. This list also includes leaders whose creativity and brands have become synonymous to markets: networks by Cisco, computers by Dell, marketplace of traders by eBay, hot coffee and cappuccino by Starbucks, fashionable clothing by Target, lowest price shopping by WalMart, low airline fares by Southwest Airlines, and search nirvana by Google. (Source:www.innovationindexgroup.com/innovation_index_fund.html16k and http://creativity and innovation.blogspot.com/2006/12/innovationindex_06.html).

\section{Innovation in Indian Information Technology Companies}

Developing an Innovation Eco-system for the Indian Information Technology Industry. This effort in particular seems to be focused on identifying opportunities for the Indian IT industry to collaborate with other stakeholders in the Indian economy to address challenges in providing more cost-effective products and services to the Indian population. Indian 
Information Technology services represented the first wave of ICT industry development in India, the BPO sector was the second major wave to drive the sector. The third wave is centered on Knowledge and Innovation. According to estimates by Frost \& Sullivan, the R\&D outsourcing market in ICT is expected to grow to $\$ 13.2$ billion by 2010 with significant technology diffusion effects. India's innovation goals are nicely captured by the slogans used to promote the 2005 and 2006 national Research and Development (R\&D) expositions in New Delhi: "Think Innovation, Think India", and "Mind to Market", and best of all, perhaps, "The World Knowledge Hub of the Future". India has 380 universities, 11,200 higher -education institutions. Annually approximately around 6,000 Ph.D.s and 2,00,000 engineers and $3,00,000$ science graduates and post-graduates are passing out. R\&D investment has been growing at a compounded annual growth rate of more than $40 \%$. More than 1, 00, 000 engineers work for the top three Indian Information Technology service giants namely, Tata Consultancy Services, Infosys and Wipro. (Source: Harold Sirkin. (January, 2007). Retrieved January 30, 2007 from http://www.businessweek. com/globalbiz/content/ jan2007/gb20070130_742264.htm).

\section{Innovation at WIPRO}

Wipro has three types of innovation: technology innovation, process innovation and delivery innovation. Wipro has an IT management council, where normally all decision about breakthrough innovations or quantum innovations are taken. To assist the IT management council, Wipro has an IT innovation council, where each project goes through four gates before an IT project gets done. At Wipro, $5 \%$ of the total revenue of $\$ 3$ billion comes from innovation projects. Mr. Azim Premji, CEO, Wipro, gets involved in key innovative projects. According to him, "Many dollars of revenue per year are earmarked for innovative projects, largely for quantum innovation and those that lead to process innovations. (Source: Sanjay Dalal. (March, 2007). Retrieved March 5, 2007 from http://creativityandinnovation.blogspot. com/2007/03/growing-global-indian-innovation.html)

\section{Innovation at Infosys}

Innovation at Infosys is grounded in the intellectual capital and the processes to rigorously train the employees. The company's key competitive advantage has been the intellectual capital of its employees. India's intellectual capital strength, economic reform, investment in quality infrastructure, and entrepreneurship made an industry offering IT solutions that were both cost-competitive and world-class.(Source : Infosys Annual Report, 2006). In India, Infosys took that idea (from GE) to heart and created the world's largest employee training facility. Indian automobile industry

24 IJMS 17 (1), 19-36 (2010) 


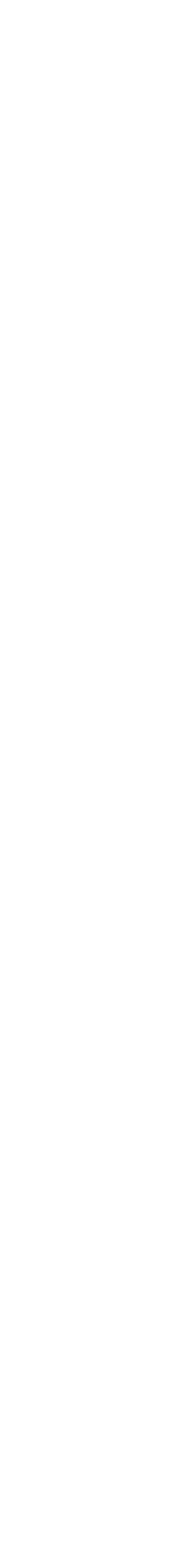

has demonstrated resounding success of Indian innovation. According to Infosys Annual Report 2006, Most Indian companies have not shown serious commitment towards developing intellectual property and innovation. For example, in 2005, Infosys spent only $0.01 \%$ of its revenue on R\&D whereas in 2006 , Infosys spent only $1.05 \%$ only. Wipro spent Rs. 27.4 crores on R\&D or $0.25 \%$ of its revenues on Research \& Development.

\section{Innovation at Tata Consultancy Services}

Tata Consultancy Services Limited (TCS) is one of the world's largest providers of information technology and business process outsourcing services. As of 2007, it is Asia's largest information technology firm and has the largest number of employees among Indian IT companies with strength of over 110,000 employees in 47 countries. The company revenues stood at US $\$ 5.7$ billion for fiscal year ended $31^{\text {st }}$ March 2008 and are listed on the National Stock Exchange and Bombay Stock Exchange in India. TCS is part of one of Asia's largest conglomerates, the Tata Group. Most of the TCS research and development laboratories are located in India. The details of those labs are TCS Innovation Lab, Convergence, TCS Innovation Lab, Delhi, TCS Innovation Lab., Embedded Systems, TCS Innovation Lab, Hyderabad, TCS Innovation Lab, Mumbai, TCS Innovation Lab, Insurance - Chennai, TCS Innovation Lab, Chennai; TCS Innovation Lab: TRDDC (Tata Research Development and Design Centre), Pune. The Tata Research Development and Design Centre, part of the TCS Innovation Labs network, was established in 1981 in Pune. It concerns itself with R\&D in software engineering and process engineering (Source: Keshto (April, 2008). Retrieved April 7, 2008 from http://www.sawaal.ibibo.com/computers-and-technology/what-uthink-about-future-tcs-79609.html).

1. In the first quarter of 2008, the Innovation Index slides $9 \%$ along with the broader market. S\&P, NASDAQ and Dow Jones have been beaten by Innovation Index by 1\%, 5\% and 1\% respectively. The Innovation Index had a banner 2007, and gained 66\% in 2007. The Innovation Index closed at 108.27 on December 31, 2007, an up $66 \%$ from the closing price of $65.05 \%$ on December 29,2006 . Only 4 Innovators out of the top 20 Innovators are in the green in 2008 and are showing modestly positive returns ranging from $1 \%$ to $7 \%$ gain. 16 out of the top 20 Innovators are in the red in 2008, with wideranging negative returns with a maximum of $36 \%$ loss (Source: Sanjay Dalal (2006). Retrieved from www.innovationindexgroup. com/ innovation_index_fund.html). Even though, India is being considered as the Information Technology Hub, India ranked much lower at $50^{\text {th }}$ place in the recent "The Global Information Technology Report 2007-2008", produced by the World Economic 
Forum in cooperation with INSEAD, the leading international business school. China fared, even worst came 7 rank lower at $57^{\text {th }}$ place. The top ten ranked nations are of the following, Denmark, Sweden, Switzerland, United States of America, Singapore, Finland, Netherlands, Iceland, Korea, and Norway. The top 25 most innovative companies as per ranking published in Business Week are of the following shown in table IV.

Table 4

Top 25 Innovative Companies as per Business Week Rankings

\begin{tabular}{clcl}
\hline Rank No. & Name of the Company & Rank No. & Name of the Company \\
\hline 1 & Apple & 2 & Google \\
3 & Toyota Motor & 4 & General Electric \\
5 & Microsoft & 6 & Nintendo \\
7 & Procter and Gamble & 8 & Sony \\
9 & Nokia & 10 & Amazon \\
11 & IBM & 12 & Research in Motion \\
13 & BMW & 14 & Hewlett-Packard \\
15 & Honda Motor & 16 & Walt Disney \\
17 & Reliance Industries & 18 & Boeing \\
19 & Goldman Sachs & 20 & $3 \mathrm{M}$ \\
21 & Wal-Mart & 22 & Target \\
23 & Samsung Electronics & 24 & AT \& T \\
25 & Face Book & & \\
\hline
\end{tabular}

Source. Business Week.

\section{Innovation Initiatives by Multinational Companies in India}

1. Microsoft and Intel launched parallel computing research centers to accelerate benefits to consumers, businesses in desktop and mobile computing in USA.

2 .

Intel launched a new program in early 2006 to encourage innovation and technology entrepreneurship. As a part of this and in association with Department of Science and Technology (DST), Government of India, India Innovation Pioneers Challenge (IIPC) 2006-2007, a technology business plan competition was launched to encourage innovation and spur commercialization of technology enterprises.

3. The Intel Higher Education Program is part of the Intel Education initiative - a sustained commitment in collaboration with educators and government leaders worldwide to help today's students prepare for the demands of tomorrow. This program works closely with premier institutions and Universities along with the Government,

26 IJMS 17 (1), 19-36 (2010) 


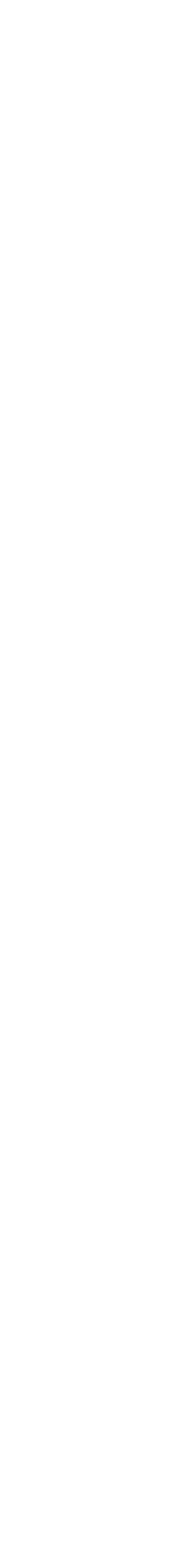

to help enrich the quality of technological and intellectual human resource available for the rapidly proliferating technology economy. 4. Initiative for Research \& Innovation in Science (IRIS) is India's largest Science fair from Intel, CII, and DST, is a merger of "Intel Science Talent Discovery fair"(ISTDf), the Indian chapter of the world's largest Science Talent Discovery initiative; and Department of Science and Technology (DST) - Confederation of Indian Industries (CII's) "Steer the Big Idea". IRIS is an initiative for infusing the spirit of discovery in school children and increasing their interest in Science \& Technology.

5. Centre for Innovation, Incubation and Entrepreneurship was setup by IIM, Ahmedabad in 2001 and is supported by Government of Gujarat and the Department of Science and Technology, Government of India. It aimed at fostering innovation-driven entrepreneurship through incubation, research and dissemination of knowledge. It was an outcome of the first national workshop on Indian Incubator for Innovation Based Enterprise (I3E) at IIMA in 1998.

\section{Research and Development (R\&D) in India}

India is becoming a global R\&D platform with more than 300 companies setting up their centres. In the last three years 30,000 scientists and researchers have returned to India to be absorbed in various organizations (Source: Business Standard). Replying in Rajya Sabha on $12^{\text {th }}$ March, 2008, Union Science and Technology Minister of India informed that number of core researchers in India was about 0.15 million as compared to China's 0.8-1 million. R\&D spending as percentage of GDP in India is only $0.8 \%$ as compared to China's $1.23 \%$. Developed countries expenditure of up to $3 \%$ of GDP. The $11^{\text {th }}$ five year plan allocations for scientific departments including departments of science and technology and atomic energy, has been increased three folds to Rs. 75, 304 crore during the $11^{\text {th }}$ Plan(2007-2012)as compared to Rs. $25,301.35$ crore during of $10^{\text {th }}$ plan period. The expenditure on R\&D as a percentage of GDP in India is lower than Brazil, China and higher than countries like Argentina, Cuba, Sri Lanka and Pakistan. India and China pour money into R\&D, offer their cheap skilled labor, and grow their vibrant economies, both countries could move into the top tier of R\&D spenders worldwide. (Source: Department of Scientific and Industrial Research (2008). Workshop Proceedings of Second Workshop on Creation and Dissemination of Knowledge. Technology Management Programme Division. Government of India. 


\section{Changing global paradigm: Percentage of worldwide R\&D spending}

Table 5

Research Spending

\begin{tabular}{lrlrlr}
\hline \multicolumn{1}{c}{2005} & \multicolumn{2}{c}{2006} & \multicolumn{2}{c}{2007} \\
\hline United States & 32.7 & United States & 32.4 & United States & 31.9 \\
Europe & 24.3 & Europe & 23.6 & Europe & 23.2 \\
Japan & 12.7 & Japan & 12.6 & Japan & 12.5 \\
China & 12.7 & China & 13.4 & China & 14.8 \\
India & 3.7 & India & 3.8 & India & 4.0 \\
\hline
\end{tabular}

Source. Battelle memorial institute and R\&D magazine's 2007 global R\&D report.

\section{India as R \& D Destination}

- Becoming the destination for innovation many world's leading organizations have started to shift their Research and Development (R\&D) Centers into Indian soil. Some of the important companies R\&D facility located in India are,

1. Lenovo launched its first India innovation center in Mumbai to expand its Indian operations. This Indian center has established in partnership with Intel, Microsoft, LANDesk, IBM and CISCO (Source:Retrieved December 29, 2006 from http://www. thehindubusinessline.com/ 2006/12/29/stories/2006122901670400. htm).

2. AMD announced the opening of a new silicon design and platform $R \& D$ facility in Bangalore which already has its operation centre in Bangalore. AMD focuses on AMD's first 45-nm quad-core MPU.

3. McAfee, Inc.'s India Centre is the development centre for McAfee around the world. The focus on the research and development of security solutions and product innovation and will take ownership of some of the key security products it creates from requirements to customer release. It is committed to invest over US \$ 80 million for the centre during 2006-2010.

4. IBM has expanded the IBM Innovation Center in Bengaluru for start-up companies, software developers, independent software vendors (ISVs), IT professionals and academics. IBM invested more than $\$ 250$ million globally in the IBM Innovation Center initiative till now. This Center assisted in the completion of more than 4, 000 technology enablement's and helped more than 9,500 developers build skills on IBM technologies.

28 IJMS 17 (1), 19-36 (2010) 
5. $\quad A B B$ has it's R\&D center in Bangalore which focuses on software development and industrial information technology.

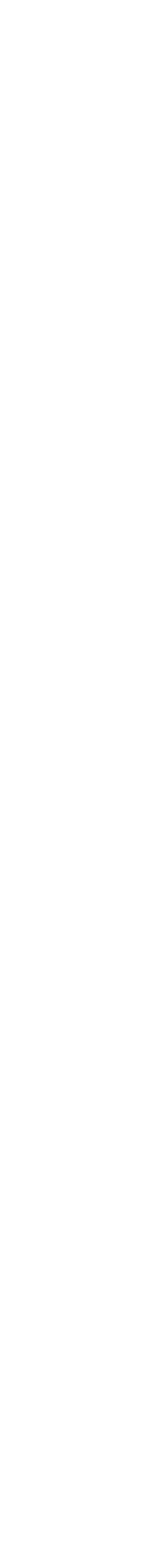

In the recent study (2007-2008) by the India Semiconductor Association (ISA) which was supported by Intel Corp. and Department of Communications and Information Technology concluded that India needs a network of dedicated research centres focusing on Chip Technology research and the government should take the lead in foreign a public-private partnership involving industry and academia. Source: Retrieved from http://www. eetindia.co.in/ART_8800510285_1800000_NT_ab0b876f.HTM\#related_div).

\section{IPR Crimes in India}

IP crime is more generally known as counterfeiting and piracy. Counterfeiting is, willful trade mark infringement, while piracy involves, willful copyright infringement. These are very similar and often overlapping crimes. IPR crime through by means of violation is a wide spread social disease and needs to be eradicated from its gross roots for which very high level of competence and experience are required. IP crime is not a new phenomenon but due to globalization and advances in technology counterfeiting and piracy has become big business.

The other crimes are Patent Violations such as infringement, Bio-piracy etc. Generally Patents alone are not usually referred as Counterfeits or Piracy. Some of the major factors contributing to the growth of IP crime are i) Widespread availability of technology, ii) Increased globalization of world trade; it is easier to manufacture in one geographic location and distribute elsewhere. The result of more open borders and more trade is that it is also easier for counterfeits to flow across borders. iii) Legal penalties are low; if they exist at all. iv)T he influence of organized crime. (Source: Altacit Global. Intellectual Property Crime. Chennai : Dr. Sudhir Ravindran \& S.A. Chenthil Kumaran. Counterfeiting and piracy have emerged as clear and serious threats to business, consumers and government. Counterfeiting is obviously a breach of consumer affairs, health, trade, and employment law. It is the negation of all the major legislation protecting individuals. Without coordinated action and policy to clamp down on the criminals and to dissuade consumers by bringing about increased awareness, a cycle of economic destabilization occurs with control slipping to the criminals.

First time Intellectual property rights were included in the Uruguay Round negotiations of the General Agreement on Tariffs and Trade (GATT), 19861993, with the Agreement on Trade-Related Aspects of Intellectual Property Rights (TRIPS). As per TRIPS, signatories should make it easier for their 
citizens and others to obtain and enforce IP rights, although it does not deal with domain names as such. TRIPS member countries should be aware that if their IP laws seem, on paper, to support innovation and protect IP, but in practice do not, they generate little besides cynicism. Conversely, costeffective means to secure, transfer, and enforce IP rights boost cultural development and standards of living, as well as promote public health and safety. Effective IP enforcement promotes a variety of other common social goals. Besides encouraging the creation of new technologies, patent and trademark laws are useful as well to prevent serious, well-documented harm posed by counterfeit goods. Local cultures (Works by local artists, authors, musicians, and others) are also at stake. These are often supported in ways that are relatively independent of the need for private risk capital.

United States of America (USA) releases "Priority Watch List" which includes the countries failing to give adequate protection to Intellectual Property Rights (IPR) such as trademarks and patents. The Special 301 Report is required by U.S. trade law. As per United States Trade Representative (USTR) report, 52 countries in 2005, 48 countries in 2006, 43 countries in 2007, 46 countries in 2008 report. India stands among top 9 in the list of Copyright infringing nations released by USA. In July 2003, an Interpol spokesperson informed Congress that the link between organized crime groups and Counterfeit goods is well established. Also Interpol sounded alarm that intellectual property crime is becoming the preferred method of funding for a number of terrorist groups. India and China are listed among nations of the highest rate IPR violations. IPR laws and enforcement are still inadequate in India. India has to focus more to improve its IPR regime by providing stronger protection for copyrights, trademarks, and patents, as well as protection against unfair commercial use of undisclosed test and other data submitted by pharmaceutical companies seeking marketing approval for their products. In criminal IPR enforcement regime improvements mostly needed in the areas of border enforcement against counterfeit and pirated goods, police action against pirates and counterfeiters, judicial dispositions resulting in convictions for copyright and trademark infringement, and imposition of deterrent sentences.

\section{IPR Enforcement Strategies}

Two of the world centers of intellectual property infringement are India and China. A series of measures have been taken by the Indian Government to make all companies TRIPS compliant. It is needed to set up special IP protection units to organize investigations, prosecutions, and raids, as well as by handling trademark and copyright registrations.

The value of intangible IP assets is a changing paradigm. IP is fast becoming a focus for capital markets and the investment community. It is a tradable

30 IJMS 17 (1), 19-36 (2010) 


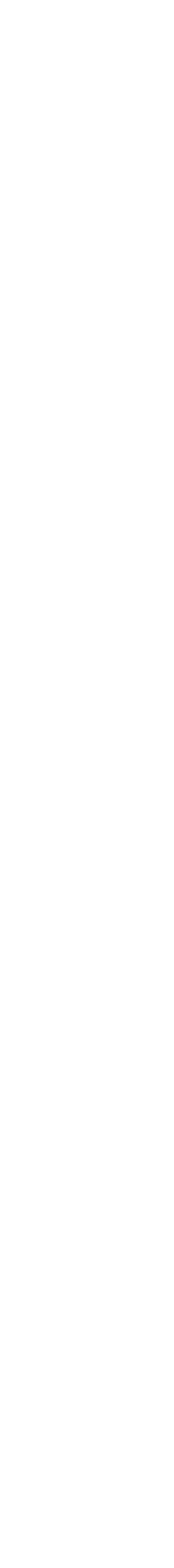

commodity in its own right and serves as a vital tool for a company's ability to sustain its competitive advantage. In U.S., Immigration and Customs Enforcement (ICE), the largest investigative arm of the Department of Homeland Security (DHS), plays a leading role in investigating the production, smuggling and distribution of counterfeit products. ICE focuses not only on keeping counterfeit products off the streets of United States of America, but also on dismantling the criminal organizational behind this activity.

IPR criminals' nature also changed. Several IPR cases that are linked to organized crime. Number of criminal organizations involved in IPR crimes found the profits associated with the sale of Counterfeit goods. ICE, along with its DHS partner made nearly 14, 000 seizures in the last fiscal year. As a result of ICE investigations, there were 241 arrests, 149 indictments and 134 convictions on IPR violations. During financial year 2007, ICE and CBP seized \$200 million worth counterfeit of pirated merchandize, which is $27 \%$ higher than the previous year. (Source: ICE Intellectual Property Rights Investigations (2008). Retrieved July 1, 2008 from http://www.ice.gov/pi/ news/factsheets/ iproverview.htm).

In India, Two-wheeler major Bajaj Auto sued its rival TVS Motors for violating its patented Digital Twin Spark ignition (DTSi) technology. DTSi engines power some of the popular Bajaj models like Pulsar and Discover which TVS Motors used for its 125 cc bike "flame" with Controlled Combustion Variable Timing intelligent (CCVTi) technology. (Source: ICE Intellectual Property Rights Investigations (2008). Retrieved July 1, 2008 from http:// www.ice.gov/pi/news/factsheets/ iproverview.htm).

\section{Enforcement of IPR - G8 Nations}

The Group Eight (G8), also known as Group of Seven and Russia, is an international forum for the governments of Canada, France, Germany, Italy, Japan, Russia, the United Kingdom and the United States of America. In June, 2007, the G8 nations declared to promote s stronger IPR system through harmonizing the global patent system to improve acquisition and protection of patent rights worldwide and stronger enforcement of IPRs in developing countries. (Source: G8 Hokkaido Tokyo Summit Leaders Declaration Hokkaido Tokyo, 8 July 2008 World Economy). The 6-point plan to strengthen enforcement of IPRs put by G8 is

a) Endorsing the Guidelines for Customs and Border Enforcement Cooperation to strengthen cooperation and coordination among our national customs and law enforcement administrations.

b) Endorsing new Guidelines for Technical Assistance on IPR protection to interested developing countries, aimed at combating 
counterfeited and pirated goods to strengthen intellectual property enforcement.

c) Improving G8 countries' cooperative actions to combat serious IPR crimes and use this as a basis to facilitate structured international cooperation regarding the investigation and prosecution of those crimes.

d) Continued study by national experts of the possibilities of strengthening the international legal framework pertaining to IPR enforcement.

e) To consider the establishment of an IPR Task Force focusing on anti-counterfeiting and piracy to look at how best to improve the working of the international IPR protection and enforcement, and produce recommendations for action.

\section{IPR Legislation in India}

- The following are the major legislations associated with IPR in India which are the Copyrights Act, 1957, The Patents Act, 1970, The Trademarks Act, 1999, The Geographical Indications of Goods (Registration and Protection) Act, 1999, The Designs Act - 2000, The Semiconductor Integrated Circuits Layout-Designs Act - 2000, The Protection of Plant Varieties and Farmers' Rights Act-2001, The Biological Diversity Act-2002. Department of Industrial Promotion Policy, Office of the Controller General Patents, TIFAC, Ministry of Human Resources Development, DRDO, FICCI, CII, ASSOCHAM, Motion Picture Association, IMI, NASSCOM, OPPI, IPA, IDMA, FIP, SISI, Central and State Universities, IITs and NITs are involved in creating awareness among students, researchers, teaching faculty members, employees of government, quasi-government, private organizations, officials from law enforcement agencies and Judiciary staff etc. Indian IPR laws provide civil remedies for all IPRs, criminal remedies for most IPRs including Patents, Copyrights, Trademarks. Provide mandatory minimum and maximum penalties, imprisonment and provide powers to police to search and seizure counterfeit and pirated products. Officials of the customs department have - powers to detain infringing goods. Specific remedies for civil infringement, notably ex-parte and interlocutory orders have been introduced. The level of penalty for criminal acts of infringement has been considerably increased. Specific powers have been given to certain police officers to enter premises, and search and seize relevant materials (without a warrant). Misuse of a trademark has been made a cognizable and non bail-able offence. Powers have been given to police officers to search and seize premises in case of trademark infringement. The Police Officer is, however, required to obtain the opinion of the Trademarks Registrar on infringement of the Trademark. The definition of 'permitted use' under the Act has been expanded to include

32 IJMS 17 (1), 19-36 (2010) 


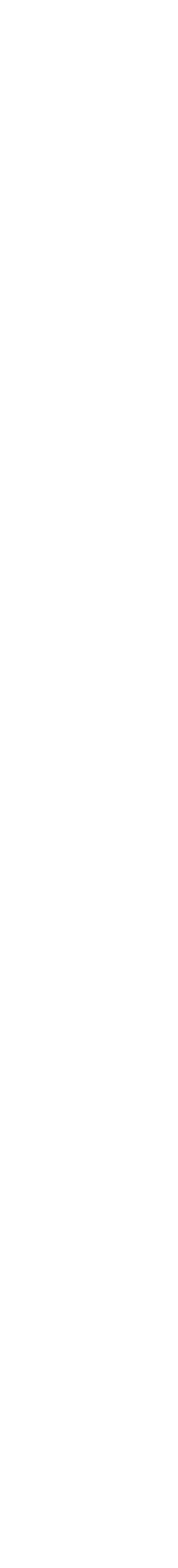

unregistered licenses'. Thus, IP owners do not need to record their license agreements with the trademarks Office. (Source: Various IPR laws, acts and rules of Government of India).

Copyright Enforcement Advisory Council in MHRD, Inter-Ministerial Coordination Committee in DIPP, Nation Crime Records Bureau, Special Cells in State Police department, Nodal Officers in States established to strengthen IPR regime in India. In the Industry side, FICCI started national initiative against piracy and counterfeiting, as a part of this draft of an Optical Disc Law to tackle Optical Disc Piracy and Programmes with Judiciary to improve coordination between Judiciary and other agencies. CII national committee on Trademark and Counterfeit Products focus on to elimination infringement and piracies. Inter-Ministerial Coordination Committee looks into all issues connected with effective enforcement, such as legislation, enforcement, sensitization and data collection. MHRD is working on to establish IPR chairs in Universities, setting up of collective administration societies for copyrights and related rights, implementing scheme on IPR education, Research and Public outreach. Ministry of I\&B involved in the development appropriate training modules for police officers for anti-piracy in the exhibition sector including multiplex and issues of certification.

Intellectual Property Appellate Board (IPAB) constituted by the Central Government in the Ministry of Commerce and Industries on $15^{\text {th }}$ September 2003 to hear appeals against the decisions of the Registrar under the Trade Marks Act, 1999 and the Geographical Indications of Goods (Registrations and Projection ) Act, 1999. It is headquartered at Chennai and shall have sittings at Chennai, Mumbai, Delhi and Kolkatta, Ahemadabad. It is necessary to train police, customs and civil servants on IPR related affairs. To improve IPR knowledge in India, more chairs and faculties in Universities and other educational institutions are need to be established. IPR should be a part of school curriculum which would help to educate both school teachers and students. Awareness programmes would provide IPR knowledge to both Stake Holders and General Public. Regular monitoring enables periodic collection and dissemination of anti-infringement activities.

All IPR activities under CII are spearheaded under CII-Nation Committee on IP Owner. The major objectives are to serve the interest of all intellectual property owners in all industries and all fields of technology. To advocate effective and affordable IP ownership rights and would provides a wide array of services to members. To concentrate on supporting members interests relating to legislative and international issues; analyzing current IP issues; providing information and educational service; and disseminating information to the general public on the importance of intellectual property rights. 
Special Cells for copyright enforcement have been set up in 23 States and Union Territories. States have been advised to designate Nodal Officer for Copyright enforcement to facilitate easy interaction by copyright industry organizations and copyright owners. There are three registered copyright societies which are Society for Copyrights Regulations of Indian Producers of films and Television (SCRIPT) for cinematography films, Indian Performing Rights Society Limited (IPRS) for musical works and Phonographic Performance Limited (PPL) for sound recordings. The PPL and the IPRS have been quite active in anti-piracy works. The PPL set up a special anti-piracy cell under a retired DGP, which has been working in tandem with the police. The following are the law enforcement agencies in India, Central Bureau of Investigation (CBI), Criminal Investigations Department (CID), Home Guards, Railway Protection Force, Rapid Action Force (RAF), Central Reserve Police Force (CRPF), Central Industrial Security Force (CISF), Central Vigilance Commission, Narcotics Control Bureau (NCB), National Security Guards (NSG), Defense Security Corps, Department of Internal Security, Special Protection Group (SPG). (Source: Embassy of India, Washington, DC. Policy Statements. Intellectual Property Rights in India. (Retrieved from http://www.indianembassy.org/special/ipr/ ipr.htm).

National Police Academy, Hyderabad and National Academy of Customs, Excise and Narcotics conducted several training programs on copyright for the police and custom officers. Modules on copyright have been included in their regular training programs.

\section{Conclusion}

This paper discussed about Indian Intellectual Property Rights regime and how innovation in India is performed which produces many IPRs. The various initiatives undertook by Government, Quasi-Government and Private Organizations to create awareness on IPR and to protect inventions by proper enforcement of IPR laws. The new IPR regime of Indian republic even though performs better, due to lack of enforcement measures not able to provide fruitful measures. Patenting scenario and the rate of assigning patents, various research and development initiatives by Indian government and other private organizations show that a better coordination is needed to enforce the existing IPR Acts. It is being concluded that partnerships between various public and private industries must be created to improve the enforcement of IPR regime in India to provide adequate protection for innovations and to motivate innovators, researchers and others involved in the $\mathrm{R} \& \mathrm{D}$ and product developments.

34 IJMS 17 (1), 19-36 (2010) 


\section{References}

Altacit Global. INTELLECTUAL PROPERTY CRIME. Chennai: Dr. Sudhir Ravindran \& S.A. Chenthil Kumara.

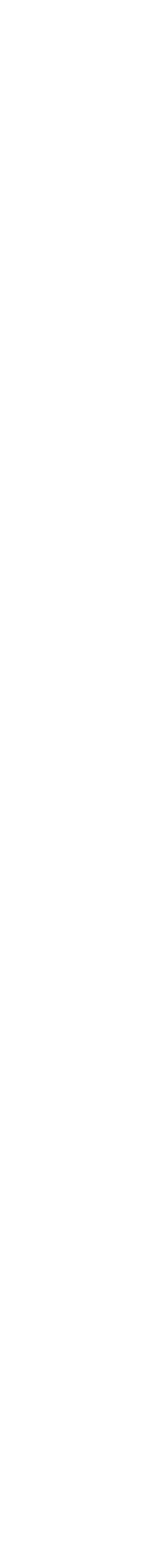

Arun Kottolli (2007). Infosys Annual Report 2006. Retrieved January 16, 2007, from http://arunkottolli.blogspot.com/2007/01/indian-style-ofinnovation-and.html

Asia Business Council (2005). Intellectual property rights: A survey of the major issues. Hong Kong: Minxin Pei.

ASSOCHAM (2007). Study on FDI Outflow and amp; Role of Manufacturing sector, and amp; Acquisitions front 2007. New Delhi.

Biju Paul A, \& Soumyo D. Moitra. (2001). Innovation assessment through patent analysis. Technovation, 21, 245-252.

Chakravarti, A.K.(1998). Protecting proprietary and security rights in cyberspace: Initiatives in India. INFOethics ' 98.

Department of Scientific and Industrial Research (2008). Workshop Proceedings of Second Workshop on Creation and Dissemination of Knowledge. Technology Management Programme Division. Government of India.

Economist Corporate Network. (2005). China: Intellectual property rights, protecting assets in the information, communications and entertainment market. (An Industry Report). Hong Kong.

EFYTimes News (2008). Retrieved June 6, 2008 from www.efytimes.com/ efytimes/26941/news.htm

Embassy of India, Washington, DC. Policy statements. Intellectual Property Rights in India. Retrieved from http://www.indianembassy.org/ special/ipr/ipr.htm

G8 Summit Declaration (2007). Growth and responsibility in the world economy. G8 Agenda for Global Growth and Stability. Heiligendamm( Germany). Retrieved August 28, 2006 from www.intel.com/cd/ corporate/educaiton/apac/eng/in/308958.htm

Harold Sirkin (January, 2007). Retrieved January 30, 2007 from http://www. businessweek.com/globalbiz/content/jan2007/gb20070130_742264. htm

Hiroki Tohya(1997). TRIPS and Policies of APEC on Intellectual Property Rights: Economic Theory and Political Reality (Working paper series 96/97 - No. 8) IDE APEC Study Center. - Report

Ibrahim Ahamadu. (2003). Intellectual property rights - A barricade to technological development - An ethical analysis on the less developed countries (Master's thesis in Applied Ethics, Linkopings University, 2003).

Infosys Technologies Limited. (2006). Infosys Annual Report, 2006.

Keshto (April, 2008). Retrieved April 7, 2008 from http://sawaal.ibibo.com/ computers-and-technology/what-u-think-about-future-tcs-379609. html 
Konstantinos, G. (2001). The economics of Intellectual Property Rights under imperfect enforcement: Developing countries, Biotechnology, and the trips agreement. EPTD discussion paper No. 80.

McAfee, Inc., (2006). Retrieved March, 2006 from http://news.thomasnet. com/companystory/481319

Moitra, S.D. (2006). Innovations in India: Criteria and obstacles. Technology Management for the Global Future. PICMET, 2(8-13), 1008-1013.

OECD \& MST. (2007). Reviews of innovation policy. China, Synthesis Report. China.

- Pawan Sikka (1998). Technological innovations by SME are in India. Technovation, 19, 317-321.

Retrieved from www.he.educaitoninindia.net/highereducation.htmInitiative for Research \& Innovation in Science (IRIS) (2008). Retrieved from www.iris.educationinindia.net/iris.htm

Sanjay Dalal (2006). Retrieved from www.innovationindexgroup.com/ innovation_index_fund.html

Sanjay Dalal (December, 2006). Retrieved December 6, 2006 from http:// creativityandinnovation.blogspot.com/2006/12/innovation-index_06. html. Sanjay Dalal (March, 2007). Retrieved March 5, 2007 from http://creativityandinnovation.blogspot.com/2007/03/growingglobal-indian-innovation.html

Singh, J.P. (2007). Copyright Issues. DESIDOC Bulletin of Information Technology, 27(6), 19-30.

Sujit Bhattacharya. (2007). Patenting in biotechnology. DESIDOC Bulletin of Information Technology, 27, (6), 31-39.

Sunil Mani. (2004). Institutional support for investment in domestic technologies: An analysis of the role of government in India. Technological Forecasting \& Social Change, 71, 855-863.

U.S. Immigration and Customs Enforcement Report (2008). Retrieved from http://www.ice.gov/pi/news/factsheets/iproverview.htm

36 IJMS 17 (1), 19-36 (2010) 